\title{
Authentic learning exercises as a means to influence preservice teachers' technology integration self-efficacy and intentions to integrate technology
}

\author{
Jennifer R. Banas \\ Northeastern Illinois University, United States of America \\ Cindy S. York \\ Northern Illinois University, United States of America
}

\begin{abstract}
This study explored the impact of authentic learning exercises, as an instructional strategy, on preservice teachers' technology integration self-efficacy and intentions to integrate technology. Also explored was the predictive relationship between change in preservice teachers' technology integration self-efficacy and change in intentions to integrate technology. Participants included 104 preservice teachers enrolled into a professional preparation methods course. Technology integration self-efficacy was measured as perceived technological knowledge (TK), pedagogical knowledge (PK), technological pedagogical knowledge (TPK), pedagogical content knowledge (PCK), and technological pedagogical content knowledge (TPACK). A paired samples t-test revealed a significant increase in self-efficacy for all TPACK constructs, as well as intentions to integrate technology. The effect was greatest for PCK. Also, multiple regression analysis revealed change in technology integration self-efficacy as a model, predicted change in intentions to integrate. Particularly change in perceived technology knowledge, predicted change in intentions. Implications for professional preparation programs are shared.
\end{abstract}

\section{Introduction}

"Despite a steady wave of how-to workshops and some longer-duration seminars, infusing technology into curriculum and teaching practices remains elusive for many teachers” (Plair, 2008; p. 70). Although technology is widely available, technology integration, defined by Lambert, Gong, and Cuper (2008) as "teachers utilizing content and technological and pedagogical expertise effectively for the benefit of students' learning” (p. 386), is often deficient in today’s classrooms (Project Tomorrow, 2008). In general, teachers are comfortable using technology for personal use or developing instructional materials, but they do not integrate it into instruction (Ertmer, 2005). When access is not the problem, what leads to inadequate integration and what can be done about it?

In part, the lack of technology integration may be due to gaps in professional preparation (Chai, Koh, \& Tsai, 2010; Haydn \& Barton, 2006; Lawless \& Pellegrino, 2007). Most teacher professional preparation programs are not constructed to strongly influence preservice teachers' technology use (Belland, 2009; Hermans, Tondeur, van Braak, \& Valcke, 2008; Kay, 2006). Programs might only include an introduction to educational technology course and methods courses demonstrate or require little to no technology integration (Brown \& Warschauer, 2006). Consequently, it is not a surprise preservice teachers do not use technology to enhance student learning when they get into their own classrooms. Such lack of integration could lead to less frequent opportunities for K-12 students to develop the twenty-first century learning skills they will need to contribute to the greater community and to be successful at their careers (Partnership for 21st Century Learning, 2011). How can professional preparation programs prepare preservice teachers to help ensure these disparities do not occur?

Anderson and Maninger (2007) and Anderson, Groulx, and Maninger (2011) indicated technology integration self-efficacy is a predictor of actual technology integration. Chai et al. (2010) and Tondeur et al. (2012) suggested preservice teachers need regular practice making connections between technology knowledge. What types of learning experiences could build these connections and foster a positive change in technology integration self-efficacy? Could these changes be determinants of changes in intentions to integrate technology? Professional preparation programs seeking to produce educators equipped to teach twenty-first century learners via technology integration would benefit from such knowledge. Previous research has examined the influence of attitudes and beliefs (Hermans et al., 2008; Kanaya, Light, \& Culp, 2005; Sang, Valcke, van Braak, Tondeur, \& Zhu, 2011), demographics (Bebell, 
Russell, \& O’Dwyer, 2004), availability of resources (Norris, Sullivan, Poirot, \& Soloway, 2003), technology skills (Chai, 2010), motivation (Litrell, Zagumny, \& Zagumny, 2005), and self-efficacy (Anderson \& Maninger, 2007; Anderson et al., 2011; Chen, 2010; Teo, 2009) on technology integration or intended technology integration. The current study investigates the impact of authentic learning exercises on preservice teachers' technology integration self-efficacy and intentions to integrate, as well as the ability of change in technology integration self-efficacy to predict changes in intention to integrate.

In the first section of the article we present the conceptual framework for the study. This includes an overview of using the TPACK framework and an associated measurement tool to determine technology integration self-efficacy, a discussion linking technology integration self-efficacy with technology integration intentions, and an argument for how authentic learning could positively influence technology integration self-efficacy. The research questions follow. In the second and third sections we present the study methodology and results. We close the article with an interpretation of the results, implications for professional preparation programs, a disclosure of study limitations, and suggestions for future research.

\section{Conceptual framework}

\section{Technological, pedagogical, and content knowledge}

Research has shown computer and software proficiency helps teachers to determine how technology might be beneficial to student learning (Angeli \& Valanides, 2009; Inan \& Lowther, 2010), but, how can one describe or measure such proficiency? One way to discuss and measure preservice teachers' technology integration self-efficacy is via the TPACK framework. TPACK (technological, pedagogical, and content knowledge) is a framework that:

emphasizes the connections among technologies, curriculum content, and specific pedagogical approaches, demonstrating how teachers' understandings of technology, pedagogy, and content can interact with one another to produce effective discipline-based teaching. (Harris, Mishra, \& Koehler, 2009; p. 396)

TPACK is comprised of three interdependent constructs—content knowledge, pedagogical knowledge, and technological knowledge -all framed within and influenced by contextual knowledge. The following are brief descriptions of each construct from Harris et al. (2009; pp. 397-399):

- Content knowledge (CK). Knowledge about subject matter to be learned or taught.

- Pedagogical knowledge (PK). Knowledge about the processes and practices of teaching and learning.

- Technological knowledge (TK). An understanding of technology that is broad enough to apply particular technologies productively.

- Pedagogical content knowledge (PCK). Teaching knowledge applicable to a specific content area.

- Technological pedagogical knowledge (TPK). An understanding of how teaching and learning change, for a given content area, when particular technologies are used.

- Technological content knowledge (TCK). An understanding of the manner in which technology and content influence and constrain one another.

- Technological pedagogical content knowledge (TPACK). Arises from the interactions among content, technological, pedagogical, and context knowledge.

But which of these specific constructs are the most influential in terms of future integration?

Some researchers have argued the lines between TPACK constructs are fuzzy and should not be separated (Angeli \& Valanides, 2009), but we argue there is some value in honing in on specific constructs. One of the most important reasons would be to ensure all constructs are addressed during a preservice teachers' professional preparation. For example, it could be easy for an educational technology course instructor to neglect the development of PK, PCK, or TPK if he/she is more focused on teaching preservice teachers how to use specific technology tools; or for a curriculum methods course instructor to neglect the development of TK and TPK by never mentioning technology as instructional tool choice. We are not 
suggesting the TPACK constructs be taught separately, rather we argue professional preparation programs need to be aware of and take steps to address all constructs over the course of preservice teachers' education particularly those that appear to be most influential. By using TPACK as a foundation for measurement and understanding, professional preparation programs can be assured they are addressing vital technology integration knowledge and skills, while more keenly focusing on the development of the TPACK constructs that most greatly affect preservice teachers' intentions to use technology. But how does one measure TPACK?

The TPACK framework has been modified and used in a number of studies to describe teacher's knowledge (Angeli \& Valanides, 2009; Archambault \& Crippen, 2009; Chai et al., 2010; Koehler \& Mishra, 2005; Koehler, Mishra, \& Yahya, 2007), but Schmidt et al. (2009) argued there was a need to develop a reliable assessment that could measure TPACK and its components. Doing so would allow one to ascertain which forms professional development work and to do not work. In response to this need they developed an instrument whose items are self-assessments of knowledge about the seven TPACK areas; CK, PK, TK, PCK, TPK, TCK, and TPACK. Questions in this instrument typically begin with the phrase "I can." In doing so the instrument aligns itself well with the concept of self-efficacy. Bandura (2006) stated the word can should be used when constructing self-efficacy assessment items as it specifically describes perceived capability. Moreover current technology integration research using the Schmidt et al. (2009) instrument has also referred to it as a measurement of self-efficacy (Abbitt, 2011; Ayegi \& Voogt, 2012; Fisser, Voogt, Ormel, Velthuis, \& Tondeur, 2011). We agree with this previous research and utilise the Schmidt et al. (2009) tool to measure preservice teachers' technology integration self-efficacy.

\section{Self-efficacy and intentions to integrate technology}

According to Tschannen-Moran and Hoy (2001), teachers' efforts, targets and desires differ depending on self-efficacy and contend "the potency of efficacy beliefs to impact teacher motivation and persistence" (p. 803) should be taken seriously. Bandura (1995) defined self-efficacy is "the belief in one's capabilities to organize and execute the courses of action required to manage prospective situations" (p. 3). Or phrased more simply, self-efficacy refers "to the belief (or perception) that one has the necessary skills and abilities to perform the behavior" (DiClemente, Crosby, \& Kegler, 2009, p. 218). A long history of self-efficacy research points to it as a known predictor of behaviour (Bandura, 1982, 1997, 2001), and more recently as predictor of both preservice and practicing teachers' technology integration. With preservice teachers, Anderson and Maninger (2007), Anderson, Groulx, and Maninger (2011), Niederhauser and Perkmen (2008), and Teo (2009) found self-efficacy to significantly predict intentions to integrate technology; and Chen (2010) found self-efficacy to significantly predict actual integration during student teaching. These findings mirror research conducted with practicing teachers. In a study of 599 teachers, Pan and Franklin (2011) found self-efficacy to be a significant predictor of teachers' use of Web 2.0 technology in K-12 classrooms. Similarly, in a mixed methods approach with six K-12 teachers, Haight (2011) found a positive correlation between self-efficacy and technology adoption. Also, Ertmer and Ottenbreit-Leftwich (2010) found while "knowledge of technology is necessary, it is not enough if teachers do not also feel confident using that knowledge to facilitate student learning” (p. 261). These findings indicate there is value in professional preparation programs attending to the types of learning experiences that positively influence preservice teachers' self-efficacy and intentions to integrate technology.

While intention does not guarantee future behaviour, well-grounded research has established it as a reliable predictor. Most notable among this research is the theory of reasoned action (Ajzen \& Fishbein, 1980; Fishbein \& Ajzen, 1975), the theory of planned behaviour (Ajzen, 1985, 1991), and the integrative model of behavioural prediction (Fishbein \& Yzer, 2003). Moreover, research related to these theories has found intention to be a predictor of future technology integration (Czerniak, Lumpe, Haney, \& Beck, 1999; Salleh \& Albion, 2004; Shiue, 2007; Venkatesh, Morris, Davis, \& Davis, 2003). Knowing which factors best predict preservice teachers' intentions to integrate technology could provide useful information to professional preparation programs seeking to design learning experiences that influence preservice teachers (Lawless \& Pellegrino, 2007). In our investigation, we sought to identify whether change in preservice teachers' perceived TPACK predicted change in intentions to integrate technology. 


\section{Authentic learning}

With the exception of clinical observation and student teaching, most preservice teachers' professional preparation lacks the contextual learning experiences afforded to in-service teachers whose technology decisions are situated in actual classroom experiences (Angeli \& Valanides, 2009). For professional preparation programs, the goal should be getting preservice teachers to view technology as a pedagogical tool to improve learning or change how learning occurs (Downes et al., 2001). Downes et al. (2001) further stated, the key is not viewing technology as a content area, but rather viewing it as a pedagogical tool that improves learning while leaving the content intact. To accomplish this, preservice teachers need regular practice making connections between technological knowledge, pedagogical knowledge, and context (Chai et al., 2010; Ertmer, 2005; Mullen, 2001). Authentic learning exercises embedded into pedagogical methods courses can facilitate this connection (Guy \& Li, 2002; Kay, 2007).

What is authentic learning? Is it an effective instructional strategy, and what might these look like in the context of teaching preservice teachers about technology integration? There is no singular criterion that makes a learning activity authentic. Rather, it is a collection of characteristics. Via an extensive review of the literature on authentic learning and related concepts, Herrington and colleagues (Herrington \& Oliver, 2000; Herrington \& Herrington, 2006; Herrington \& Kervin, 2007; Herrington, Oliver, \& Reeves, 2003) have established a list of characteristics to describe authentic learning. These included that authentic learning will:

- Have real-world significance.

- Be ill-defined.

- Require learners to define tasks and sub-tasks needed to complete the activity.

- Be complex tasks to be investigated over a sustained period of time.

- Provide learners with the opportunity to examine the task from different perspectives using a variety of resources.

- $\quad$ Provide the opportunity to collaborate.

- Provide the opportunity to reflect.

- Be integrated and applied across different subject areas and beyond domain-specific outcomes.

- Be seamlessly integrated with assessment.

- Create polished products valuable in their own right.

- Allow for competing solutions and diversity of outcomes.

Summarised, authentic learning is a multidisciplinary, pedagogical approach that allows learners, under the guidance of their instructors, to explore, discuss, and meaningfully construct concepts and relationships in the context of real problems and projects (Donavan, Bransford, \& Pellegrino, 1999; Herrington \& Herrington, 2006).

Authentic learning has been identified as an effective instructional strategy because it requires learners to make connections to existing knowledge and to explore new knowledge deeply in context (Lombardi, 2007). The contextual nature of the authentic learning experiences promotes deeper learning because of their associations with a setting, activities, and people (Lombardi, 2007). Seminal research conducted by Resnick (1987) and more recently McConachie et al. (2006) and Resnick and Zurawsky (2007), asserted these experiences could bridge the gap between theoretical learning and real-life application. This could be the same bridge Chai et al. (2010) described as needing to be made between technology, pedagogy, and context. A few technology-specific, authentic learning studies revealed this might be true. For example, Kurz and Middleton (2006) found providing preservice teachers with opportunities to practice and reflect on the pedagogical uses of a software program not only led to more positive beliefs about the technology, but also more skilful insight into its constraints and affordances. Pope, Hare, and Howard (2002) found exposure to technology integration in the context of learning about pedagogy had a direct impact on preservice teachers' efficacy and use of technology during student teaching. Similarly, Kay (2007) found having preservice teachers replicate technology integration tasks performed by classroom teachers was a significant predictor of preservice teachers' technology use during student teaching. These studies demonstrate that authentic learning exercises may be a means to bridge the contextual gap between technology and pedagogy, and to influence preservice teachers' intentions to integrate. 
In light of the characteristics identified by Herrington and colleagues (Herrington \& Oliver, 2000; Herrington \& Herrington, 2006; Herrington \& Kervin, 2007; Herrington et al., 2003), authentic learning exercises that promote technology integration could take on a variety of formats. These may include learning exercises that require preservice teachers to work in teams to develop technology integrated curriculum units and/or individual lesson plans that could be implemented in a real classroom setting. Next, they could practice delivering a technology-integrated lesson to classmates as a practice audience and reflect on best ways to implement the lesson again in the future. Prior to these lesson implementations, preservice teachers would be given the time to practice using different technologies while also considering how those technologies could help future students achieve learning objectives. The underlying intention of such exercises would be to help preservice teachers connect new experiences to existing knowledge, to understand how technology can support teaching and learning, and to foster the self-efficacy to do so. In the current study, preservice teachers performed all of the activities described above. A detailed description is provided in the Methods section.

\section{Purpose}

The purpose of this study was to investigate whether authentic learning exercises, as an instructional strategy embedded into a methods course, could positively impact preservice teachers' self-efficacy to integrate technology and intentions to integrate. Also, we sought to identify predictive relationships between the changes in technology integration self-efficacy and the changes in intentions. According to Dalecki and Willits (1991), studying change (i.e., difference) scores is a viable way to assess the impact of varying events on a desired outcome. In the current study, if a significant predictive relationship was found between changes in self-efficacy and changes in intentions, that could build a case for continued research into using authentic learning exercises to improve preservice teachers' self-efficacy. To that end, the following research questions were examined:

1. Do authentic learning exercises influence preservice teachers' technology integration selfefficacy and intentions to integrate technology (IIT)?

2. Does change in technology integration self-efficacy predict change in intentions?

\section{Methods}

\section{Context}

This study took place in the lead researcher's Health Education in the Middle and High Schools course. Participants were students taking this course during the 2011-2013 academic year at a university in the Midwest region of the United States. The course was a 3-credit, undergraduate level, required methods course for preservice teachers working towards a health education endorsement. While health education was the content matter, development of curriculum and instruction skills was the primary course goal. As the course instructor, the lead researcher's professional background includes a doctoral degree in instructional design and technology, a master's degree in curriculum and instruction, and six years of 6th9th grade health education teaching experience.

\section{Study design}

With Institutional Review Board (IRB) approval, pre- and post-assessments took place during Weeks 4 and 13 of the 15 week long semester. The study design is depicted in Table 1. To maintain anonymity, names of participants were not associated with their responses; rather, pre- and post-responses were matched via a coded first question, the participant's former elementary school name and the name of the street that they lived on in 3rd grade. To avoid potential bias resulting from the researcher also being the course instructor, a colleague read a description of the study when the researcher was out of the room and provided the preservice teachers with a link to the assessment. She also indicated the study was voluntary and there were no penalties for not participating. The indirect benefits were described as promoting continual improvement in professional preparation for teachers. 
Table 1

Research design

\begin{tabular}{lll}
\hline \multicolumn{1}{c}{ Week 4} & \multicolumn{1}{c}{ Week 5-12 } & \multicolumn{1}{c}{ Week 13 } \\
\hline $\begin{array}{l}\text { TPACK and intentions } \\
\text { pre-assessment }\end{array}$ & $\begin{array}{l}\text { Authentic learning experiences with } \\
\text { technology integration }\end{array}$ & $\begin{array}{l}\text { TPACK and intentions } \\
\text { post-assessment }\end{array}$ \\
& $\begin{array}{l}\text { Curriculum unit and technology } \\
\text { integrated lesson plans } \\
\text { Lesson presentations }\end{array}$ \\
&
\end{tabular}

\section{Participants}

All of the 104 preservice teachers enrolled into the methods course chose to participate in the study. Sixty participants were male and, 44 were female. Ages of participants ranged from 20 to 42 years old, with 84.9\% being 20-27 years old. Education levels were as follows: 17.9\% high school diploma, 67\% associate's degree, $11 \%$ bachelor's degree, and $4.1 \%$ masters degree. In light of their existing education, and with the exception of one student who indicated some prior training, all participants indicated they were novices in developing curriculum and instruction that integrated technology. All were working towards an endorsement in either health or physical education.

\section{Treatment: Authentic learning exercises}

The authentic learning exercises consisted of preservice teachers developing a 3-4 weeklong curriculum unit and 4 complete lesson plans in teams of 3-4 students. They also delivered one of the lesson plans to classmates as if their classmates were 6th-12th grade students. These exercises were scaffolded over 8 weeks of the course. The exercises are described in detail below.

\section{Technology integrated curriculum units}

In the fourth week of the course, preservice teachers formed teams to develop a 3-4 weeklong curriculum unit for a selected health education content area (e.g., substance use and abuse, nutrition, mental health, reproductive health, etc.). A typical unit length in health education is 3-4 weeks, and this was considered to be a manageable task for the course. The design of the unit was rooted in the Backwards Design curriculum and instruction model (Wiggins \& McTighe, 2005). The Backwards Design model is a three stage conceptual framework that has demonstrated to lead to higher levels of student performance (Kelting-Gibson, 2005). In Stage 1, the instructor identifies the overall goal of the unit, desired student learning outcomes (i.e., objectives), and state and/or national learning standards with which the learning outcomes align. In Stage 2, the instructor determines how they would assess student achievement of the objectives and develops appropriate assessment tools. In Stage 3, the instructor identifies learning activities that will ensure student achievement of the objectives and organises these learning activities sequentially into a planning calendar.

In the current study, preservice teachers completed all three stages of the Backwards Design process to develop a unit whose objectives, assessments, and learning activities could be implemented in future classroom setting. Due to the brevity of the course, only brief descriptions of proposed daily learning activities, versus detailed lesson plans, were required in the Stage 3 planning calendar. After the preservice teachers completed Stage 3, the lead researcher introduced the technology-integrated lesson plans (described next) as an authentic learning exercise. Upon completion of these lessons, the preservice teachers returned to Stage 3 of their curriculum unit and selected which previously described learning activities could be enhanced with technology and modified those descriptions to reflect the technology enhancements. The last step of the unit project required preservice teachers to construct a cover page and a summary describing their unit. In this summary, they were required to describe how technology was used to enhance student learning and to cite specific examples.

\section{Technology-integrated lesson plans}

Over a 2 week period, preservice teachers practiced using different types of technology tools and designed four detailed technology-integrated lessons. Specifically, these lessons were intended to expand 
on four or more of the proposed learning activities briefly described in their Stage 3 planning calendar. The different types of technology tools included:

- Idea/concept mapping and other information visualisation tools.

- Audiovisual tools.

- Online surveys and other information gathering tools.

- Blogging, wikis, websites, and other information sharing tools.

To guide development of the lesson plans, each preservice teacher was provided a detailed lesson plan template which required him/her to provide the following items: (1) a summary of the learning activity and a description of how the technology tool would be used during instruction; (2) a list of desired student learning outcomes; (3) a step-by-step lesson outline with particular attention to directions that would ensure students could independently and successfully use the selected technology tool; and (4) grading criteria for student performance. The preservice teachers were also asked to develop a prototype of completed student work. The intention behind requiring the prototype was to get preservice teachers thinking about the order and detail of the directions future students would need to successfully complete the assigned task and what difficulties those students might encounter.

Delivery and reflection on a technology-integrated lessons

After receiving feedback from the lead researcher on the four technology-integrated lesson plans, preservice teachers selected and delivered one of the lessons to their classmates as if classmates were 6th12th grade students. They also administered and pre- and post-test to assess achievement of the desired learning outcomes. The classroom in which these lessons were implemented was a computer lab, thus affording each classmate with a computer. Also a projector and screen was made available to the preservice teachers acting as instructors. After implementation, both the presenters and the audience discussed the strengths and weaknesses of the lesson. Next, they graded the pre- and post-assessments to evaluate learning outcomes. Finally, they submitted a reflection about what aspects of the lesson they felt went well and what changes they would make for future implementation. The purpose of this latter activity was to engage preservice teachers in the thought process of carefully considering those factors that make for a successful technology-integrated learning activity.

Overall, the intention of these three sets learning exercises was to provide preservice teachers with illdefined situations to practice making the types of instructional decisions made by a classroom teacher who regards technology as a tool to enhance student learning. Moreover, they were able to perform these activities in collaboration with others, with support from their peers and instructors, and with opportunities for reflective practice. Each of these characteristics aligns with the description of authentic learning depicted earlier in this article.

\section{Instrumentation}

To examine the research questions, a pre- and post-assessment was administered to both course sections prior to the first authentic learning experience (approximately the beginning of Week 4) and after the last learning experience (approximately Week 13). The pre- and post-assessments were identical and were divided into three parts. In Part 1, each participant rated their agreement with statements about their TPACK. In Part 2, they rated their intention to integrate technology in their future classroom. In Part 3, participants provided demographic data including age, gender, major, and previous technology integration training. Parts 1 and 2 are described next and also appear in the Appendix A.

Part 1 - TPACK

Each participant's TPACK was measured using 28 items adapted from Schmidt et al. (2009) TPACK assessment tool. The questions used in the current study utilised 5 of the 7 TPACK subscales including technological knowledge (TK; 6 items), pedagogical knowledge (PK; 6 items), pedagogical content knowledge (PCK; 7 items), technological pedagogical knowledge (TPK; 4 items), and technological pedagogical content knowledge (TPACK; 5 items). The content knowledge (CK) subscale was excluded from the survey because preservice teachers were given the option to choose from several health education sub-content areas, therefore making it difficult to assess content knowledge using only a 7-item instrument. The integrity of most questions was maintained, although the researchers re-worded the PCK questions and deleted one TPK and one PK question. The PCK questions were re-worded to reflect health 
education content/skills areas taught to K-12 student audiences instead of the math, science, literacy, and social studies skills in the original Schmidt et al. (2009) instrument. The TPK question beginning with "My teacher education program has caused me ..." was removed because the instrument was not intended to evaluate the whole professional preparation program. The PK question, "I know how to organize and maintain classroom management." was deleted because classroom management was not an integral part of the methods course. The Cronbach's alpha reliability coefficient for each subscale was as follows; TK (Cronbach's $\alpha=.872$ ), PK (Cronbach's $\alpha=.847$ ), PCK (Cronbach's $\alpha=.924)$, TPK (Cronbach’s $\alpha=$ .842 ), and TPACK (Cronbach's $\alpha=.901$ ). These values suggest high internal consistency (Hair, Black, Babin, Anderson, \& Tatham, 2006). All questions were based on a 7-point Likert-type scale.

Part 2 - Intention to integrate technology

Intentions to use technology to enhance teaching and student learning was measured using three items reflecting the intention subscale of Fishbein's (2000) Integrative Model of Predictive Behavior (IMPB). This model, an extension of the Theory of Reasoned Behavior (Ajzen 1985, 1991) and Social Cognitive Theory (Bandura, 1986, 1997), assesses the influence of attitudes, norms, and self-efficacy on intention to perform a behaviour. It also purports that environmental factors and skills/ability work with intention to influence behaviour. Because intention to use technology was perceived as a behaviour that could be influenced by beliefs and skills (such as self-efficacy and technology integration) this subscale was ideal. Moreover, this model has been used recently to explain preservice teachers' intentions to use technology (Admiraal, Lockhorst, Smit, \& Weijers, 2013 Kreijns,Vermeulen, Kirschner, Van Buuren, \& Van Acker, 2013). Computing the mean score for all three items created a singular intention variable. The Cronbach's alpha reliability coefficient for the 3-item subscale was determined to be .972 . The three questions were based on a 7-point Likert scale.

\section{Results}

\section{Data analysis}

The Statistical Package for Social Science (SPSS) Version 20 was used to analyze the data. To analyse research question one, a paired samples t-test, also referred to as a repeated-measures test, was used to calculate differences between pre-test and post-test scores. To identify the size of the treatment effect, Cohen's $d$ was calculated for the five TPACK constructs and single IIT variable. To analyse research question 2, standard multiple regression, using the enter method, was used to assess the ability of the change in technology integration self-efficacy to predict change in intentions to integrate technology. Tests for multicollinearity were performed and are reported with the research question 2 results. Means and standard deviations were also calculated.

Impact of authentic learning exercises on technology integration self-efficacy and intentions

The purpose of research question number one was to investigate the impact of the authentic learning exercises, as an instructional strategy embedded into a methods course, on preservice teachers' technology integration self-efficacy and intentions to integrate. Technology integration self-efficacy was measured as perceived technological knowledge (TK), pedagogical knowledge (PK), pedagogical content knowledge (PCK), technological pedagogical knowledge (TPK), and technological pedagogical and content knowledge (TPACK). Paired-samples t-tests revealed a statistically significant increase in all TPACK constructs (i.e., technology integration self-efficacy) as well as intentions to integrate technology. This means that the authentic learning exercises may have positively impacted the preservice teachers' technology integration self-efficacy. To identify the magnitude of the treatment effect, Cohen's $d$ was calculated for all variables. Effect sizes ranged from .23 to .89 (see Table 2). Based on Cohen's (1988) convention, $d=.80$ indicates a large effect, $d=.50$ indicates a medium effect, and $d=.20$ indicates a small effect. This means the effect of the authentic learning exercises was large for PCK, moderate or approaching moderate for PK, TPK, and TPACK, and small for TK and intention to integrate technology. In other words, of all the TPACK constructs, the authentic learning exercises seemed to make the greatest impact on perceived pedagogical content knowledge. Perceived pedagogical content knowledge assessment items were as follows:

1. I can select technologies to help students comprehend health promotion and disease prevention concepts. 
2. I can select technologies to help students analyze the influence of family, peers, culture, media, technology, and other factors on health behaviours.

3. I can select technologies to help students to access valid information, products, and services to enhance health.

4. I can select technologies to help students use interpersonal communication skills to enhance health and avoid or reduce health risks.

5. I can select technologies to help students use goal-setting skills to enhance health.

6. I can select technologies to help students practice health-enhancing behaviours and avoid or reduce health risks.

7. I can select technologies to help students advocate for personal, family, and community health.

Looking at these assessment items, it appears that authentic learning exercises may have helped the preservice teachers to apply the use of technology to specific content areas in health education. Harris et al. (2009) asserted "[p]edagogical content knowledge is the intersection and interaction of pedagogy and content knowledge” (p. 398). Knowing how to forge links and connections among different content-based ideas make up part of this construct, along with assessment and reporting of learning. In the current study, these skills were practiced by way of designing a technology-enhanced curriculum unit and designing, developing, implementing, and evaluating a lesson plan that integrated technology. These authentic learning exercises could have strengthened the preservice teachers' perceived pedagogical content knowledge and possibly the other TPACK constructs.

Table 2

Results of paired-samples t-tests for TPACK constructs

\begin{tabular}{lccccccc}
\hline & $\mathrm{N}$ & Mean & SD & SE & $\mathrm{t}$ & $P$ & ES \\
\hline Pre-TK & 104 & 5.06 & 1.18 & .12 & 3.85 & $.00^{* *}$ & .38 \\
Post-TK & 104 & 5.50 & 1.13 & .11 & & & \\
Pre-PK & 104 & 5.33 & .92 & .09 & 4.82 & $.00^{* *}$ & .64 \\
Post-PK & 104 & 5.88 & .77 & .08 & & & \\
Pre-PCK & 104 & 4.87 & 1.07 & .17 & 5.73 & $.00^{* *}$ & .89 \\
Post-PCK & 104 & 5.80 & 1.01 & .16 & & & \\
Pre-TPK & 104 & 5.65 & .84 & .08 & 3.57 & $.00^{* *}$ & .41 \\
Post-TPK & 104 & 6.01 & .93 & .09 & & & \\
Pre-TPACK & 104 & 5.52 & .95 & .11 & 4.82 & $.00^{* *}$ & .69 \\
Post-TPACK & 104 & 6.17 & .93 & .10 & & & \\
Pre-IIT & 104 & 6.06 & 1.18 & .12 & 2.07 & $.05^{*}$ & .23 \\
Post-IIT & 104 & 6.32 & 1.05 & .10 & & & \\
\hline Notes & & & & & & &
\end{tabular}

Notes:

* Significant at the .05 level

** Significant at the $<.01$ level

TK $=$ Technological knowledge

$\mathrm{PK}=$ Pedagogical knowledge

PCK = Pedagogical, content knowledge

TPK = Technological, pedagogical knowledge

TPACK $=$ Technological, pedagogical, and content knowledge

IIT $=$ Intention to integrate technology

Relationship between change in technology integration self-efficacy and change in intentions

The purpose of research question 2 was to investigate the relationship between change in preservice teachers' technology integration self-efficacy and change in their intentions to integrate. Change in technology integration self-efficacy was measured as change in perceived technological knowledge (TK), pedagogical knowledge (PK), pedagogical content knowledge (PCK), technological pedagogical knowledge (TPK), and technological pedagogical and content knowledge (TPACK) from pre- to postassessment, as were changes in intentions. Again, the value in studying change (i.e., difference) scores is to assess the impact of events on a desired outcome (Dalecki \& Willits, 1991). In the current study, we 
sought to find a positive relationship between improved technology integration self-efficacy and changes in intentions to integrate technology.

To investigate a potential relationship, multiple regression analysis, via the enter method, was performed. Performing a multiple regression analysis assumes lack of multicollinearity. Multicollinearity exists when more than two predictors correlate very strongly. When this happens, it creates biased estimates between variables. Collinearity diagnostics were performed and they did not reveal violations. In accordance with Pallant (2010), tolerance values were high (above .10) and variance inflation factor (VIF) values were low (below 10), both suggesting the likelihood of multicollinearity (and biased estimates) was low. Moreover, bivariate correlation values were below .70, therefore omission of variables was not considered (Pallant, 2010). Correlations appear in Table 3; tolerance and VIF values appear in Table 4.

Table 3

Correlations between TPACK constructs

\begin{tabular}{lllllll}
\hline & IITd & TKd & PKd & PCKd & TPKd & TPACKd \\
\hline IITd & -- & $.38^{* *}$ & .15 & $.20^{*}$ & -.02 & .09 \\
TKd & $.38^{* *}$ & -- & .07 & .11 & -.08 & .09 \\
PKd & .15 & .07 & -- & $.30^{* *}$ & $.53^{* *}$ & $.48^{* *}$ \\
PCKd & $.20^{*}$ & .11 & $.30^{* *}$ & -- & .14 & $.31^{* *}$ \\
TPKd & -.02 & -.08 & $.53^{* *}$ & .14 & -- & $.65^{* *}$ \\
TPACKd & .09 & .09 & $.48^{* *}$ & $.31^{* *}$ & $.65^{* *}$ & -- \\
\hline
\end{tabular}

Notes:

$* \mathrm{p}<0.05$ level

$* * \mathrm{p}<0.01$ level

IITd = Change in intention to integrate technology

$\mathrm{TKd}=$ Change in technological knowledge

$\mathrm{PKd}=$ Change in pedagogical knowledge

PCKd = Change in pedagogical, content knowledge

TPKd = Change in technological, pedagogical knowledge

TPACKd = Change in technological, pedagogical, and content knowledge

Table 4

Linear regression results and collinearity diagnostics

\begin{tabular}{llllllll}
\hline & $B$ & SE $(B)$ & $\beta$ & $T$ & $P$ & Tolerance & VIF \\
\hline TKd & .31 & .08 & .35 & 3.75 & .00 & .95 & 1.06 \\
PKd & .10 & .10 & .11 & .98 & .33 & .65 & 1.53 \\
TPKd & .22 & .17 & .13 & 1.29 & .20 & .85 & 1.18 \\
PCKd & -.06 & .14 & -.05 & -.42 & .68 & .49 & 2.05 \\
TPACKd & .00 & .13 & .00 & .02 & .98 & .51 & 1.96 \\
\hline
\end{tabular}

Notes:

$\mathrm{SE}=$ Standard error

VIF $=$ Variance inflation factor

TKd $=$ Change in technological knowledge

$\mathrm{PKd}=$ Change in pedagogical knowledge

PCKd = Change in pedagogical, content knowledge

TPKd = Change in technological, pedagogical knowledge

TPACKd = Change in technological, pedagogical, and content knowledge

The regression analysis revealed change in preservice teachers' technology integration self-efficacy predicted their change in intentions to integrate technology. The total variance explained by the model was $16.93 \%, F(5,98)=4.00, \mathrm{p}<.001$. Change in technology knowledge $(\mathrm{TKd})$ predicted significantly, 
recording a beta value $(\beta=.35, \mathrm{p}<.001)$. PK, PCK, TPK, and TPACK did not significantly predict (see Figure 1 and Table 4). This means improving preservice teachers' technology knowledge self-efficacy, more so than the other TPACK constructs, may lead to a positive development in intentions to integrate technology. Perceived technology knowledge assessment items were:

1. I know how to solve my own technical problems.

2. I can learn technology easily.

3. I keep up with important new technologies.

4. I frequently play around with the technology.

5. I know about a lot of different technologies.

6. I have the technical skills I need to use technology.

These items represent the types of skills a preservice teacher would need to be able to perform in order to evolve "over a lifetime of generative interactions with multiple technologies" (Harris et al., 2009; p. 398). This means it would behoove professional preparation to focus on the improvement of preservice teachers' perceived technology knowledge. Based on the results of research question 1, authentic learning exercises may be a means to do so.

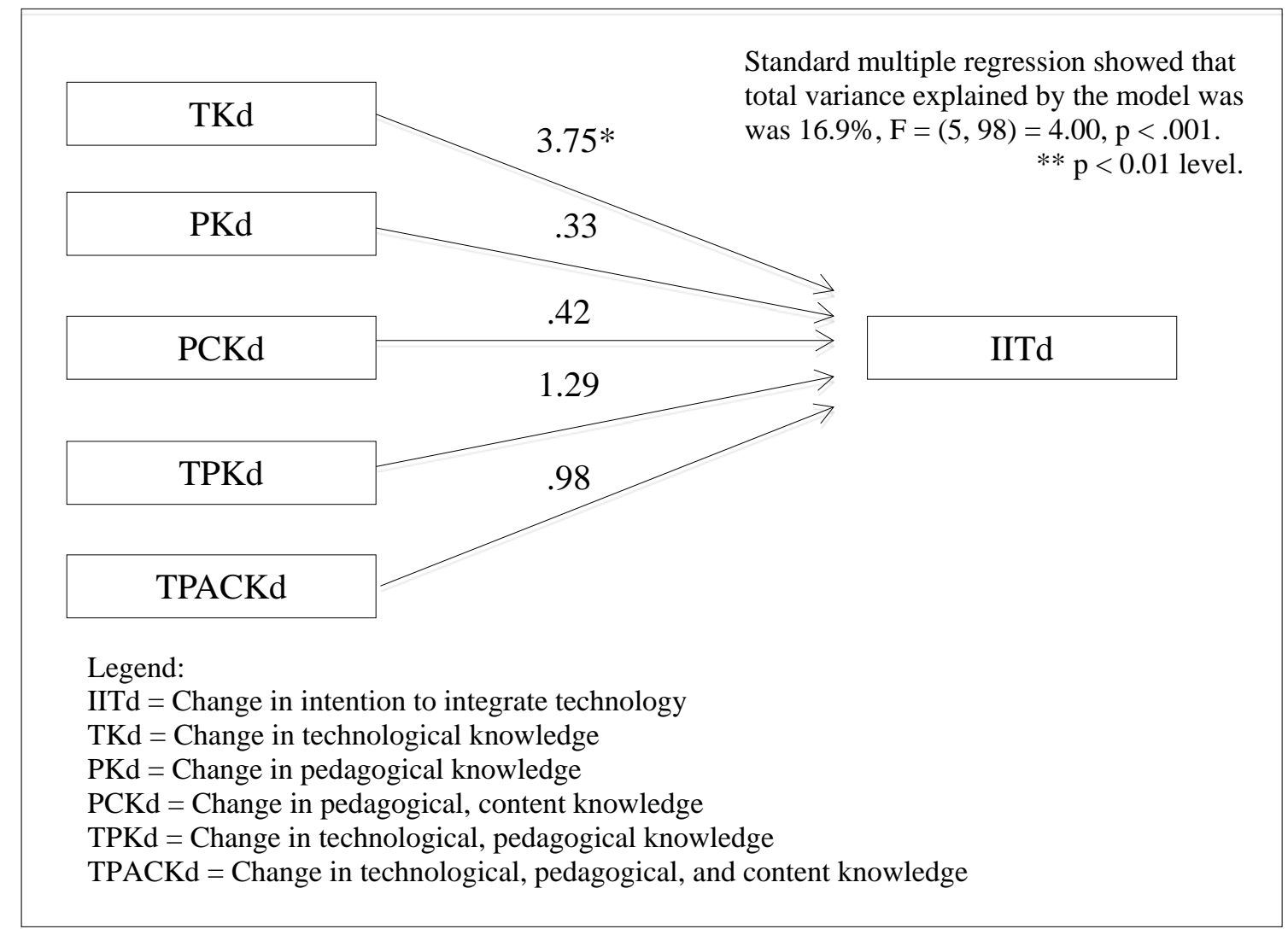

Figure 1. Results of standard regression: Ability of TPACK and its constructs to predict intention

\section{Discussion}

Authentic learning is a natural fit for promoting the development of self-efficacy for a given set of skills. Bandura (1986, 2001) stated the single most powerful method of altering self-efficacy is via performance attainment (i.e., mastery). Successful interventions provide learners with opportunities to partake in incremental, structured learning activities that allow for self-monitoring and elicit feedback from a valued individual, such as their instructor. The combination of these events can increase learners' self-efficacy to perform the target behaviour (Bandura, 1986, 2001). In the current study, preservice teachers were exposed to incremental, guided, authentic learning exercises while receiving constructive feedback from their peers and instructor. Study results indicate these authentic learning exercises may have positively 
altered their technology integration self-efficacy and intentions to integrate technology. Study results also show the positive change in perceived technology knowledge might have predicted the positive change in intentions to integrate.

Results from research question one revealed a significant change in all perceived TPACK constructs and intentions, with the greatest results reported for PCK, followed by PK, TPK, and TPACK. Effects were small for perceived TK and intentions. The significant change in the pedagogy-related constructs is not surprising given the large emphasis placed on pedagogical skill development in the context of health education. Study participants developed lesson plans and curriculum units in the context of health education. Specifically, they learned how to write standards-aligned learning objectives, assess student achievement of desired, learning outcomes, and develop appropriate learning activities using the Backwards Design (Wiggins \& McTighe, 2005) curriculum and instruction model. In all of these exercises, technology was regarded as an instructional tool, not a focal point. While preservice teachers did learn how to use at least four new technology tools, the primary emphasis was identifying ways these technologies could support student achievement of the desired learning outcomes.

The small effect on perceived technology knowledge and intentions to integrate could be due to a ceiling effect. Scores for both of these variables were already high when the first measurement was taken. It is also possible the authentic learning exercises did not influence their technology knowledge skills and intentions. According to Harris et al. (2009), technological knowledge (TK) includes those skills that help one to mitigate new technologies and considered to be a vital skill set given the rapid flux of technology. This would mean the authentic learning exercises or other activities might need to hone in more on developing these skills. A scaffold approach might begin with a teacher educator conducting a thinkaloud discussion about navigating a new technology. He or she could project the technology's interface on a screen at the front of room and engage students in dialogue about how to find first-timer tools like a tutorial, a help button, sample products, or a list of frequently asked questions. Next, the preservice teachers could work in small groups to navigate assigned new technologies with the potential for being integrated into instruction. Finally, the preservice teachers would work individually with new technologies to develop a lesson plan that integrates them. The idea here would be to provide the preservice teachers techniques on how to approach a new technology and eventually build their selfefficacy to do so. Given the relationship found between changes in perceived technology knowledge and changes in intention to integrate (discussed later in this section), it is important to investigate these findings further.

While the effect was not large for all TPACK constructs, the outcomes are promising. Mishra and Koehler (2006) stressed the importance of developing capacity for deepening learning with technology. The authentic learning exercises implemented in the current study are one way to do this. This idea is supported by Chai et al. (2010) who identified having preservice teachers practice integrating technology into planned instruction is a worthwhile strategy to improve preservice teachers' technology integration skills. The results also reflect other research in which authentic learning exercises were found to improve preservice teachers' self-efficacy to perform the tasks of a practicing teacher. For example, RussellBowie (2012) found her preservice art teachers' confidence increased after a series of activities that mimicked the tasks of a classroom art teacher. These activities included writing lesson plans that integrated arts across the curriculum and designing a school-based art program. These tasks are similar to the authentic exercises in the current study. In another example, Ogden, DeLuca, and Searle (2010) found having preservice music teachers take on the role of a music teacher designing, developing, and implementing a music production led to increased confidence.

The second research question investigated the relationship between the change in preservice teachers' perceived technology integration self-efficacy (measured as TPACK) and its ability to predict the change in intentions to use technology. Findings revealed the change in TPACK, as a whole model, predicted change in intention to integrate technology; however, only the change in technology knowledge (TKd) predicted significantly. Change in perceived PK, TPK, PCK, and TPACK did not predict. Previous research found pedagogical beliefs (Anderson et al., 2011; Chen, 2010; Ravitz, Becker, and Wong, 2000), technology knowledge (Chai, 201), or technology-related self-efficacy (Anderson \& Maninger, 2007; Anderson et al., 2011; Chen, 2010; Litrell et al., 2005; Teo, 2009) predicted technology integration or intentions to integrate. The current study investigated whether the change in technology integration selfefficacy predicted the change in intentions from pre- to post-assessment. The findings mean the 
magnitude of change in preservice teachers' self-efficacy to integrate technology predicts the magnitude of changes in intentions. In other words, if there is little change in preservice teachers' self-efficacy to integrate, one also should expect to see little change in their intentions to integrate; and if there are great changes in preservice teachers' technology integration self-efficacy, one also should expect to see great changes in intentions.

Knowing intentions have the potential to predict future integration (Czerniak et al., 1999; Salleh \& Albion, 2004; Shiue, 2007; Venkatesh et al., 2003), there is value in professional preparation programs seeking out the kinds of learning experiences that most greatly increase preservice teachers' self-efficacy to integrate and consequently their intentions. Because the change in perceived technology integration self-efficacy (measured as TPACK) as a whole model predicted the change in intention and because change in perceived technological knowledge was a significant predictor, it might be wise to also develop the TPACK constructs together. Angeli and Valanides (2009) found TPACK, as a whole, to be a unique form of knowledge whose constructs should not be separated out and taught uniquely. This means development of technology knowledge, the construct whose change predicted the change in intention, should not be taught exclusively; rather, it should be taught within the context of using a given technology to improve teaching and student learning. This also complies with Koehler and Mishra (2005) who stated:

Good teaching is not simply adding technology to the existing teaching and content domain. Rather, the introduction of technology causes the representation of new concepts and requires developing a sensitivity to the dynamic, transactional relationship between all three components suggested by the [TPACK] framework. (p. 134)

Teaching preservice teachers to use technology when it is pedagogically appropriate, not just because it exists, is crucial in order for preservice teachers to understand when and why to integrate technology (Willis, 2001). Given that educational technologies come and go frequently, providing preservice teachers with strategies to navigate new technologies and doing so in the context of designing instruction makes sense.

\section{Limitations}

Regarding limitations, there are several worth mentioning. First, this study occurred in a naturalistic setting and did not include a control group. Use of a control group would strengthen the research design and provide more insight into the influence of the learning activities. Also, TPACK does not function in a vacuum; other external and internal factors could have been at play (Angeli \& Valanides, 2009). Interviews and focus groups, more frequent assessments, and open-ended questions might help to identify such influential factors. A second limitation relates to course content. This study was conducted in a health education methods course. While the design of a curriculum unit and lesson plans are learning activities that could be implemented in any methods course, replication of this study in other subject areas would strengthen the study design. Third, while perceived technology integration self-efficacy accounted for almost $17 \%$ of the variance in intention, there remains $83 \%$ that is not explained. Future studies conducted with larger populations could investigate the influence of other variables. These variables could include previously studied variables such as access to technology and attitudes towards technology integration. Fourth, this study was not longitudinal; therefore, it could not affirm whether or not perceived technology integration self-efficacy predicted actual future use. More studies are needed which follow preservice teachers from their professional programs into future classroom settings. Finally, perceived ability to integrate technology does not necessarily translate into one's ability to effectively integrate technology. Bandura (1986) warned there is always a risk for discrepancy between confidence and actual ability. In all, these limitations point towards opportunities to continue developing our understanding about best ways to prepare preservice teachers to integrate technology and increasing the likelihood that they do. 


\section{Conclusion}

Understanding the factors that influence preservice teachers' technology integration intentions could help teacher educators to better design professional preparation. Results from this study indicate authentic learning experiences embedded into a methods course had a positive impact on preservice teachers' technology integration self-efficacy and intentions to integrate technology. Results also indicated the change in preservice teachers' technology integration from pre- to post-assessment predicted the change in their intentions to integrate. Specifically the change in perceived technology knowledge predicted the change in intentions to integrate technology. This means the degree to which perceived technology knowledge improves is mirrored by improvements in preservice teachers' intentions to integrate technology.

Harris et al. (2009) contended technological knowledge, compared to pedagogical knowledge and content knowledge, is always in a state of flux given the rate at which technology changes. Professional preparation programs should focus not only on developing preservice teachers' technology integration skills, but also provide them with the skills to navigate new technologies. However, this does not mean these skills should be taught exclusive of the other skills represented by the TPACK framework. Rather, continued exposure to and practice with the types of instructional decisions made by practicing teachers can only help preservice service teacher to make the needed connections between technology knowledge and pedagogical knowledge in order to become effective integrators of technology (Chai et al., 2010; Tondeur et al., 2012). The goal, ultimately, is to have preservice teachers thinking about the best tools for instruction and means by which to enhance student learning.

\section{References}

Abbitt, J. T. (2011). An investigation of the relationship between self-efficacy beliefs about technology integration and technological pedagogical content knowledge (TPACK) among preservice teachers. Journal of Digital Learning in Teacher Education, 27(4), 134-143.

Admiraal, W., Lockhorst, D., Smit, B., \& Weijers, S. (2013). The integrative model of behavior prediction to explain technology use in post-graduate teacher education programs in the Netherlands. International Journal of Higher Education, 2(4), 172-178.

Anderson, S. E., Groulx, J. G., \& Maninger, R. M. (2011). Relationships among preservice teachers' technology-related abilities, beliefs, and intentions to use technology in their future classrooms. Journal of Educational Computing Research, 45(3), 321-338.

Anderson, S. E., \& Maninger, R. M. (2007). Preservice teachers' abilities, beliefs, and intentions regarding technology integration. Journal of Educational Computing Research, 37(2), 151-172.

Angeli, C., \& Valanides, N. (2009). Epistemological and methodological issues for the conceptualization, development, and assessment of ICT-TPACK: Advances in technological pedagogical content knowledge (TPACK). Computers and Education, 52, 154-168.

Ajzen, I. (1985). From intentions to actions: A theory of planned behavior. In J. Kuhl \& J. Beckman (Eds.), Action-control: From cognition to behavior (pp. 11- 39). Heidelberg, Germany: Springer.

Ajzen, I. (1991). The theory of planned behavior. Organizational Behavior and Human Decision Processes, 50, 179-211.

Ajzen, I., \& Fishbein, M. (1980). Understanding attitudes and predicting social behavior. Englewood Cliffs, NJ: Prentice-Hall.

Archambault, L., \& Crippen, K. (2009). K-12 Distance educators at work: Who's teaching online across the United States. Journal of Research on Technology in Education, 41(4), 363-391.

Ayegi, D. D., \& Voogt, J. (2012). Developing technological pedagogical content knowledge in preservice mathematics teachers through collaborative design. Australasian Journal of Educational Technology, 28(4), 547-564.

Bandura, A. (1982). Self-efficacy mechanism in human agency. American Psychologist, 37(2), 122-147.

Bandura, A. (1986). Social foundations of thought and action. Englewood Cliffs, NJ: Prentice Hall.

Bandura, A. (1995). Self-efficacy in changing societies. Cambridge, MA: University Press.

Bandura, A. (1997). Self-efficacy: The exercise of control. New York: Freeman.

Bandura, A. (2001). A social cognitive theory: An agentic perspective. Annual Review of Psychology, 52, 1-26. 
Bandura, A. (2006). Guide for constructing self-efficacy scales. In F. Pajares \& T. Urdan (Eds.). Selfefficacy beliefs of adolescents (Vol. 5, pp. 307-337). Greenwich, CT: Information Age Publishing.

Bebell, D., Russell, M., \& O’Dwyer, L. M. (2004). Measuring teachers' technology uses: Why multiplemeasures are more revealing. Journal of Research on Technology in Education, 37(1), 45-63.

Belland, B. R. (2009). Using the theory of habitus to move beyond the study of barriers to technology integration. Computers and Education, 52, 353-364.

Brown, D., \& Warschauer, M. (2006). From the university to the elementary classroom: Students' experiences in learning to integrate technology in instruction. Journal of Technology and Teacher Education, 14(3), 599-621.

Chai, C. S. (2010). The relationship among Singaporean preservice teachers' ICT competencies, pedagogical beliefs and their beliefs on the espoused use of ICT. The Asia-Pacific Education Researcher, 19(3), 387-400.

Chai, C. S., Koh, J. H. L., \& Tsai, C. C. (2010). Facilitating preservice teachers' development of technological, pedagogical, and content knowledge (TPACK). Journal of Educational Technology \& Society, 13(4), 63-73.

Chen, R. (2010). Investigating models for preservice teachers' use of technology to support studentcentered learning. Computers and Education, 55, 32-42.

Cohen, J. (1988). Statistical power analysis for the behavioral sciences. (2nd ed.). Hillsdale, NJ: Lawrence Erlbaum Associates.

Czerniak, C. M., Lumpe, A. T., Haney, J. J., \& Beck, J. (1999). Teachers’ beliefs about using technology in the science classroom. International Journal of Educational Technology, 1(2), 1-18.

Dalecki, M., \& Willits, F. K. (1991). Examining change using regression analysis: three approaches compared. Sociological Spectrum, 11, 127-145.

DiClemente, R. J., Crosby, R. A., \& Kegler, M. (2009). Emerging theories in health promotion practice and research. Hoboken, NJ: John Wiley \& Sons.

Donovan, M. S., Bransford, J. D., \& Pellegrino, J. W. (1999). How people learn: Bridging research and practice. Washington, DC: National Academy Press.

Downes, T., Fluck, A., Gibbons, P., Leonard, R., Matthews, C., Oliver, R...Williams, M. (2001). Making better connections: Models of teacher professional development for the integration of information and communication technology into classroom practice. Canberra, AU: Commonwealth Department of Education, Science and Training.

Ertmer, P. A. (2005). Teacher pedagogical beliefs: The final frontier in our quest for technology integration. Educational Technology Research \& Development, 53(4), 25-39.

Ertmer, P. A., \& Ottenbreit-Leftwich, A. (2010). Teacher technology change: How knowledge, confidence, beliefs, and culture intersect. Journal of Research on Technology in Education, 42(3), 255-284.

Fishbein, M. (2000). The role of theory in HIV prevention. AIDS Care, 12, 273-278.

Fishbein, M., \& Ajzen, I. (1975). Belief, attitude, intention, and behavior: An introduction to theory and research. Reading, MA: Addison-Wesley.

Fishbein, M., \& Yzer, M. C. (2003). Using theory to design effective health behavior interventions. Communication Theory, 13, 164-183.

Fisser, P., Voogt, J., Ormel, B., Velthuis, C., \& Tondeur, J. (2011, March). Prospective teachers’ selfefficacy of TPACK in the science domain. Paper presented at the annual meeting of the Society for Information Technology \& Teacher Education, Nashville,TN.

Guy, M. D., \& Li, Q. (2002, April). Integrating technology into an elementary mathematics methods course: Assessing the impact on pre- service teachers' perception to use and teach with technology. Paper presented at the annual meeting of the American Educational Research Association, New Orleans, LA.

Haight, K. W. (2011). The adoption and integration of technology within the classroom: Teacher selfefficacy beliefs. Retrieved from ERIC database. (ED526375)

Hair, J. F. Jr., Black, W. C., Babin, B. J., Anderson, R. E., \& Tatham, R. L. (2006). Multivariate data analysis (6th ed.). Englewood Cliffs, NJ: Prentice-Hall.

Harris, J., Mishra, P., \& Koehler, M. (2009). Teachers' technological pedagogical content knowledge and learning activity types: Curriculum-based technology integration reframed. Journal of Research on Technology in Education, 41(4), 393-416.

Haydn, T., \& Barton, R. (2006). Common needs and different agendas: How trainee teachers make progress in their ability to use ICT in subject teaching. Some lessons from the UK. Computers and Education, 49, 1018-1036. 
Hermans, R., Tondeur, J., van Braak, J., \& Valcke, M. (December 2008). The impact of primary school teachers' educational beliefs on the classroom use of computers. Computers and Education, 51, 14991509.

Herrington, A., \& Herrington, J. (2006). Authentic learning environments in higher education. Hershey, PA: Information Science Publishing.

Herrington, J., \& Kervin, L. (2007). Authentic learning supported by technology: Ten suggestions and cases of integration in classrooms. Educational Media International, 44(3), 219-236. doi:10.1080/09523980701491666

Herrington, J., \& Oliver, R. (2000). An instructional design framework for authentic learning environments. Educational Technology Research and Development, 48(3), 23-48.

Herrington, J., Oliver, R., \& Reeves, T. (2003). Patterns of engagement in authentic online learning environments. Australian Journal of Educational Technology, 19(1), 59-71.

Inan, F. A., \& Lowther, D. L. (2010). Factors affecting technology integration in K-12 classrooms: A path model. Educational Technology Research and Development, 58(2), 137-154.

Kanaya, T., Light, D., \& Culp, K. (2005). Factors influencing outcomes from a technology-focused professional development program. Journal of Research on Technology in Education, 37, 313-329.

Kay, R. H. (2006). Evaluating strategies used to incorporate technology into preservice education: A review of the literature. Journal of Research on Technology in Education, 38(4), 383- 408.

Kay, R. H. (2007). A formative analysis of how preservice teachers learn to use technology. Journal of Computer Assisted Learning, 23(5), 366-383.

Kelting-Gibson, L. M. (2005). Comparison of curriculum development practices. Educational Research Quarterly, 29(1), 26-36.

Koehler, M. J., \& Mishra, P. (2005). What happens when teachers design educational technology? The development of technological pedagogical content knowledge. Journal of Educational Computing Research, 32(2), 131-152.

Koehler, M. J., Mishra, P., \& Yahya, K. (2007). Tracing the development of teacher knowledge in a design seminar: Integrating content, pedagogy, \& technology. Computers and Education, 49, 740762.

Kreijns, K., Vermeulen, M., Kirschner, P. A., Van Buuren, H., Van Acker, F. (2013). Adopting the integrative model of behaviour prediction to explain teachers' willingness to use ICT: A perspective for research on teachers' ICT usage in pedagogical practices. Technology, Pedagogy and Education, 22, 55-71.

Kurz, T. L., \& Middleton, J. A. (2006). Using a functional approach to change preservice teachers' understanding of mathematics software. Journal of Research on Technology in Education, 39(1), 4565.

Lambert, J., Gong, Y., \& Cuper, P. (2008). Technology, transfer and teaching: The impact of a single technology course on preservice teachers' computer attitudes and ability. Journal of Technology and Teacher Education, 16(4), 385-410.

Lawless, K. A., \& Pellegrino, J. W. (2007). Professional development in integrating technology into teaching and learning: knows, unknowns, and ways to pursue better questions and answers. Review of Educational Research, 77(4), 575-614.

Littrell, A. B., Zagumny, M. J., \& Zagumny, L. L. (2005). Contextual and psychological predictors of instructional technology use in rural classrooms. Educational Research Quarterly, 29(2), 37-48.

Lombardi, M. M. (2007). Authentic learning for the 21st century: An overview. Retrieved from http://net.educause.edu/ir/library/pdf/ELI3009.pdf

McConachie, S., Hall, M., Resnick, L., Ravi, A. K., Bill, V. L., Bintz, J., \& Taylor, J. A. (2006). Task, text, and talk. Educational Leadership, 64(2), 8-14.

Mishra, P., \& Koehler, M. J. (2006). Technological pedagogical content knowledge: A framework for teacher knowledge. Teachers College Record, 108(6), 1017-1054.

Mullen, L. (2001). Beyond infusion: Pre-service students' understandings about educational technologies for teaching and learning. Journal of Technology and Teacher Education, 9(3), 447-466.

Niederhauser, D. S., \& Perkmen, S. (2008). Validation of the intrapersonal technology integration scale: Assessing the influence of intrapersonal factors that influence technology integration. Computers In The Schools, 25(1-2), 98-111.

Norris, C., Sullivan, T., Poirot, J., \& Soloway, E. (2003). No access, no use, no impact: Snapshot surveys of educational technology in K-12. Journal of Research on Technology in Education, 36(1), 15-27.

Ogden, H., DeLuca, C., \& Searle, M. (2010). Authentic arts-based learning in teacher education: A musical theatre experience. Teaching Education, 21(4), 367-383. 
Pallant, J. (2010). SPSS survival manual. (4th ed.) New York, NY: Open University Press.

Pan, S., \& Franklin, T. (2011). In-service teachers' self- efficacy, professional development, and Web 2.0 tools for integration. New Horizons in Education, 59(3), 28-40.

Partnership for 21st Century Learning. (2011). Framework for 21st century learning. Retrieved from http://www.p21.org/storage/documents/1._p21_framework_2-pager.pdf

Plair, S. (2008). Revamping professional development for technology integration and fluency. The Clearing House, 8(2), 70-74.

Pope, M., Hare, P., \& Howard, E. (2002). Technology integration: Closing the gap between what preservice teachers are taught to do and what they can do. Journal of Technology and Teacher Education, 10, 191-203.

Project Tomorrow. (2008). 21st century learners deserve a 21st century education. Selected National Findings of the Speak Up 2007 Survey. Retrieved from http://www.tomorrow.org/docs/national\%20findings\%20speak\%20up\%202007.pdf

Ravitz, J., Becker, H., \& Wong, Y. (2000). Constructivist-compatible beliefs and practices among U.S. teachers (Report No. 4). Center for Research on Information Technology and Organizations, University of California, Irvine and University of Minnesota. Retrieved from: http://www.crito.uci.edu/tlc/html/findings.html

Resnick, L. B. (1987). Education and learning to think. Washington, D.C.: National Academies Press.

Resnick, L. B., \& Zurawsky, C. (2007). Science education that makes sense. American Educational Research Association. Research Points, 5(1), 1-4. Retrieved from http://legacy.aera.net/uploadedFiles/Journals_and_Publications/Research_Points/RP_Summer07.pdf

Russell-Bowie, D. (2012). Developing preservice primary teachers' confidence and competence in arts education using principles of authentic learning. Australian Journal of Teacher Education, 37(1), 6074.

Salleh, S., \& Albion, P. (2004, March). Using the theory of planned behavior to predict Bruneian teachers' intentions to use ICT in teaching. Proceedings of the Society for Information Technology and Teacher Education International Conference 2004 (pp. 1389-1396), Chesapeake, VA: AACE.

Sang, G., Valcke, M., van Braak, J., Tondeur, J., \& Zhu, C. (April, 2011). Predicting ICT integration into classroom teaching in Chinese primary schools: Exploring the complex interplay of teacher-related variables. Journal of Computer Assisted Learning, 27(2), 160-172.

Schmidt, D. A., Baran, E., Thompson, A. D., Mishra, P., Koehler, M. J., \& Shin, T. S. (2009). Technological pedagogical content knowledge (TPACK): The development and validation of an assessment instrument for preservice teachers. Journal of Research on Technology in Education, 42(2), 123-149.

Shiue, Y. (2007). Investigating the sources of teachers' instructional technology use through the decomposed theory of planned behavior. Journal of Educational Computing Research, 36(4), 425453.

Teo, T. (2009). Modeling technology acceptance in education: A study of pre-service teachers. Computers and Education, 52, 302-312.

Tondeur, J., van Braak, J., Sang, G., Voogt, J., Fisser, P., \& Ottenbreit-Leftwich, A. (2012). Preparing pre-service teachers to integrate technology in education: A synthesis of qualitative evidence. Computers and Education, 59, 134-144.

Tschannen-Moran, M., \& Hoy, A. W. (2001). Teacher efficacy: Capturing an elusive construct. Teaching and Teacher Education, 17, 783-805.

Venkatesh, V., Morris, M. G., Davis, G. B., \& Davis, F. D. (2003). User acceptance of information technology: Toward a unified view. MIS Quarterly, 27(3), 425-478.

Wiggins, G., \& McTighe, J. (2005). Understanding by design. (2nd ed.). Upper Saddle, NJ: Pearson Education.

Willis, J. (2001). Foundational assumptions for information technology and teacher education. Contemporary Issues in Technology and Teacher Education, 1(3), 305-320. 


\section{Appendix A Assessment Instrument}

Directions: Indicate your agreement with the statements below using the following scale:

disagree:____:_2_:_3_:_4_:_5_:_6___7_ agree

Part 1 - Technological pedagogical content knowledge

Technology Knowledge (TK)

1. I know how to solve my own technical problems.

2. I can learn technology easily.

3. I keep up with important new technologies.

4. I frequently play around with the technology.

5. I know about a lot of different technologies.

6. I have the technical skills I need to use technology.

Pedagogical Knowledge (PK)

7. I can assess student performance in a classroom.

8. I can adapt my teaching based upon what students currently understand or do not understand.

9. I can adapt my teaching style to different learners.

10. I can assess student learning in multiple ways.

11. I can use a wide range of teaching approaches in a classroom setting.

12. I am familiar with common student understandings and misconceptions.

Pedagogical Content Knowledge (PCK)

13. I can select technologies to help students comprehend health promotion and disease prevention concepts.

14. I can select technologies to help students analyze the influence of family, peers, culture, media, technology, and other factors on health behaviors.

15. I can select technologies to help students access valid information, products, and services to enhance health.

16. I can select technologies to help students use interpersonal communication skills to enhance health and avoid or reduce health risks.

17. I can select technologies to help students use goal-setting skills to enhance health.

18. I can select technologies to help students practice health-enhancing behaviors and avoid or reduce health risks.

19. I can select technologies to help students advocate for personal, family, and community health. Technological Pedagogical Knowledge (TPK)

20. I can choose technologies that enhance the teaching approaches for a lesson.

21. I can choose technologies that enhance students' learning for a lesson.

22. I am thinking critically about how to use technology in my future classroom.

23. I can adapt the use of the technologies that I am learning about to different teaching activities.

Technological Pedagogical Content Knowledge (TPACK)

24. I can teach lessons that combine technology and teaching approaches for health education content and skills.

25. I can select technologies to use in my future classroom that enhance what I teach, how I teach, and what students learn.

26. I can use strategies that combine health education content and skills, technologies, and teaching approaches in my future classroom.

27. I can provide leadership in helping others to coordinate the use of content, technologies, and teaching approaches at my future school and/or district.

28. I can choose technologies that enhance the content for a health education lesson.

Part 2 - Intention to integrate technology (IIT)

29. I plan to use technology as a tool to enhance student learning.

30. I will use technology as a tool to enhance student learning.

31. I intend to put effort into using technology as a tool to enhance student learning. 
Australasian Journal of Educational Technology, 2014, 30(6).

Corresponding author: Jennifer R. Banas, jenbanas@gmail.com

Australasian Journal of Educational Technology (C) 2014.

Please cite as: Banas, J., \& York, C. (2014). Authentic learning exercises as a means to influence preservice teachers' technology integration self-efficacy and intentions to integrate technology. Australasian Journal of Educational Technology, 30(6), 728-746. 